\title{
Evaluation of Some New Wine Grape Cultivars under São Francisco Valley Conditions
}

\author{
Patrícia Coelho de Souza Leão ${ }^{1}$, Bruna Thaís Gonçalves Nunes ${ }^{2}$, Emille Mayara Carvalho de Souza ${ }^{2}$, Jéssica \\ Islane de Souza Rego ${ }^{2}$ and José Henrique Bernardino do Nascimento ${ }^{2}$ \\ 1. Embrapa Semiárido, BR 428, Km 152, Zona Rural, PO Box 23, Petrolina 56302-970, Pernambuco State, Brazil \\ 2. Universidade de Pernambuco (UPE), Petrolina 56302-970, Pernambuco State, Brazil
}

\begin{abstract}
This study aimed to evaluate the performance and characteristics of the grapes as subsidies to the recommendation of new wine grape cultivars for the São Francisco Valley. An experiment was carried out in Petrolina, Pernambuco state, during four seasons in 2014 and 2015 and the treatments were represented by 10 cultivars and three breeding selections: Grenache, Tempranillo, Merlot, Cabernet Sauvignon, Malbec, Petit Verdot and Syrah for red wines and Sauvignon Blanc, Chardonnay, Chenin Blanc and breeding selections 46, 14 and 47 for white wines. The experimental design was a randomized block with four replicates and two useful plants per plot. The following variables were evaluated: sprouting, bud fertility rate, Ravaz index, production, number of clusters, weight, length and width of cluster, weight and volume of 100 berries, soluble solids and titratable acidity. A better balance between production and vigour was obtained in Grenache, Merlot and Tempranillo cultivars, presenting values of 7.56, 6.50 and 5.93, respectively, for Ravaz index. Grenache, Chenin Blanc and Tempranillo were the most productive cultivars with average yields estimated at 10.4, 8.7 and 8.4 ton/ha/season. Selection 14 had longer, wider and less compact clusters, which can reduce clusters rottenness. The percentage of sprouting ranged from $38.13 \%$ in selection 14 to $77.6 \%$ in $\mathrm{cv}$. Chenin Blanc. The average index of bud fertility was 0.79 cluster/bud, with no significant differences among cultivars. Greater potential for sugar accumulation was found in the selections 14, 46 and 47, while the titratable acidity ranged from $0.63 \%$ in cv. Merlot to $0.89 \%$ in selection 47 . Grenache and Tempranillo have showed potential to obtain adequate yield and balanced vines, while Sauvignon Blanc, Chardonnay, Cabernet Sauvignon, Malbec and Petit Verdot presented low yield being necessary to select clones more productive and well adapted to the tropical conditions. Further information about the quality of grapes and wines should be added to these results to allow the recommendation of new cultivars or breeding selections of wine grapes for the São Francisco Valley.
\end{abstract}

Key words: Tropical viticulture, wine grape, yield.

\section{Introduction}

São Francisco Valley is one of the most important grape and wine producing region in the country, reaching 9,703 ha harvested and a production of 315,338 tons in 2015 [1]. Although there is no official statistics for the production of wine in the northeastern region of Brazil, it is estimated that the production of five million litters, which gives this region the second position, is behind the Rio Grande do Sul state [2].

The traditional production of wine in the world is on two regions. One located between latitudes $35^{\circ}-50^{\circ}$

Corresponding author: Patrícia Coelho de Souza Leão, Ph.D., research fileds: genetics and grape breeding.
$\mathrm{N}$, which includes the grape growing areas of California, in the United States and European countries (Portugal, Spain, France, Germany and Italy), and another between parallels $29^{\circ}-45^{\circ} \mathrm{S}$, where are Chile, Argentina, South of Brazil, South Africa, Australia and New Zealand. The semiarid region of Northeastern Brazil is located between parallels $8^{\circ}-10^{\circ} \mathrm{S}$, with an average annual temperature of $26.5{ }^{\circ} \mathrm{C}$, precipitation of $540 \mathrm{~mm}$ and insolation of $3,000 \mathrm{~h} /$ year [3].

Viticulture in semiarid tropical climate began in the late $60 \mathrm{~s}$, with the introduction of grape for fresh consumption and wine purpose, advancing and developing one of the most peculiar wine regions in 
the world. As in tropical conditions, the vine does not come at rest, it maintains its vegetative growth throughout the year. So, it is possible to meet plants in different growth stages in the same time and same production area, achieving up to two crops annually. The management of the vineyard requires the water supply for irrigation and the control of vegetative growth by a water stress for 30-60 d after harvest. The shoots have strong apical dominance and budding is obtained by the application of hydrogen cyanamid [4].

The wines of the São Francisco Valley, known as "sun wine", are characterized as young wines, fruity and aromatic, although they are also designed guard wines, which undergo some time in oak barrels and promote greater complexity of aromas and an improvement in the structure of the wines [5].

Thus, the São Francisco Valley has broken known wine world paradigms and overcome the disbelief of those who thought that was impossible to produce quality wines in tropical conditions. However, the appeal of tropical wines, distinction of product and versatility to explore different types, varietals combinations and production times throughout the year bring many technological challenges, among which are the differential potential of cultivars, characterizing the typicality of raw materials and finished products, the adjustment in management and winemaking techniques [6].

The most important cultivars of grapes for winemaking in the São Francisco Valley are Syrah for red wines, Chenin Blanc for white wines and Muscat cultivars for sparkling wines [5]. The last one has emerged as the most appreciated and sales leader in the region.

Further studies, including cultivars already used by local wineries and other economically important in other countries of the world, should be studied to identify grape cultivars well adapted to tropical conditions. This study aimed to evaluate vegetative growth, yield and fruit quality of the grapes as subsidies to the recommendation of new wine grape cultivars for the São Francisco Valley conditions.

\section{Materials and Methods}

This experiment was carried out in Bebedouro Experimental Station, Embrapa Semiárido, in Petrolina, Pernambuco state $\left(9^{\circ} 09^{\prime} \mathrm{S}, 40^{\circ} 22^{\prime} \mathrm{W}, 365.5\right.$ m) over four production growing seasons during 2014 to 2015 (two crops per year with harvest in June and December of each year). The first harvest was in June 2014, one year after planting approximately. According to the Köppen climate classification, the climate is tropical semiarid, BSwh type, dry and warm, with average annual temperature around $26^{\circ} \mathrm{C}$, annual rainfall about $500 \mathrm{~mm}$, concentrated between the months of January and April [3].

The vines of all cultivars were planted at the same time in June 2013, grafted on rootstock "IAC 766", spaced $3.0 \mathrm{~m} \times 1.0 \mathrm{~m}$ and drip irrigated.

The canopy management included pruning and shoot thinning. As the shoots were grown, they were attached to the trellis wires and trimmed at the top of the trellis. Other cultural practices were weed control by applying herbicides and trench, fertigation and phytosanitary treatments as recommended for viticulture in the São Francisco Valley [4].

The vines have been trained in a vertical upward shoot positioned trellis, spur pruned on bilateral cordon with an average of six spurs per plant.

The treatments were represented by 10 grape cultivars and three Embrapa grape breeding selections for winemaking: Grenache, Tempranillo, Merlot, Cabernet Sauvignon, Malbec, Petit Verdot and Syrah for red wines and Sauvignon Blanc, Chardonnay, Chenin Blanc and breeding selections 46, 14 and 47 for white wines.

The experimental design was a randomized block with four replications and two plants per plot. They were evaluated in four consecutive growing seasons for the following variables: sprouting (\%), bud fertility rate (cluster/shoot), Ravaz index ( $\mathrm{kg}$ of grapes $/ \mathrm{kg}$ of pruned branches), production ( $\mathrm{kg} / \mathrm{vine}$ ), 
number of clusters per vine, weight $(\mathrm{g})$, length $(\mathrm{cm})$ and width $(\mathrm{cm})$ of cluster, weight $(\mathrm{g})$ and volume $(\mathrm{mL})$ of 100 berries, soluble solids ( ${ }^{\circ}$ Brix) and titratable acidity (\% of tartaric acid).

On the pruning dates, all the shoots and leaves were removed. The leaves and herbaceous branches removed from the pruned material were gathered up and weighed. At harvest, the clusters were counted and weighed. Average cluster weight was obtained by dividing total weights of the clusters by numbers of clusters for each plant. The ratio of bunch weight and branch weight was calculated, obtaining the Ravaz index. During the sprouting phase and initial shoot growth, the number of buds, shoots and clusters was registered, obtaining the sprouting percentage (number of sprouted buds $\times 100$ /number of buds) and bud fertility (number of bunches $x$ $100 /$ number of shoots).

During the harvest, all clusters of evaluated plants were counted, harvested and weighed to obtain the production per plant. A sample of five clusters was taken to the Embrapa Semiárido Postharvest Physiology Laboratory, to determine the measures of length and width of the cluster, weight and volume of 100 berries. A soluble solid content was obtained in an Abbe digital refractometer [7], as well as titratable acidity was determined by titration in a $0.1 \mathrm{M} \mathrm{NaOH}$ solution [7].

Mean data from four production growing seasons were submitted to variance analysis and comparison of means by Tukey test at $5 \%$ probability.

\section{Results and Discussion}

There was influence of genotype of wine grapes cultivars and breeding selections on the components of production and physicochemical characteristics of bunches and berries, with the exception of bud fertility where there were no differences among cultivars.

The percentage of sprouting ranged from $38.13 \%$ in selection 14 to $77.59 \%$ in the cultivar Chenin Blanc. Sprouting lower and less than $55 \%$ were obtained in Malbec, Petit Verdot and selections 47 and 14 (Table 1). Although there were no observed differences among cultivars and selections, the bud fertility rates were high, from 0.79 (Cabernet Sauvignon) to 1.10 (Syrah).

Table 1 Mean sprouting (\%), bud fertility rate (bunch/shoot), production (kg) and number of clusters per vine of wine grape cultivars and breeding selections, Petrolina, Pernambuco state, 2014 and 2015 seasons.

\begin{tabular}{lllll}
\hline Cultivars/selections & SP & BF & PR & NC \\
\hline Grenache & $69.30^{\mathrm{ab}}$ & $0.96^{\mathrm{ns}}$ & $3.11^{\mathrm{a}}$ & $11.79^{\mathrm{bcd}}$ \\
Chenin Blanc & $77.59^{\mathrm{a}}$ & 0.98 & $2.62^{\mathrm{ab}}$ & $12.26^{\mathrm{bcd}}$ \\
Tempranillo & $61.44^{\mathrm{ab}}$ & 0.96 & $2.53^{\mathrm{ab}}$ & $10.61^{\mathrm{bcd}}$ \\
Selection 46 & $68.81^{\mathrm{ab}}$ & 0.99 & $2.17^{\mathrm{b}}$ & $13.06^{\mathrm{bc}}$ \\
Syrah & $68.19^{\mathrm{ab}}$ & 1.10 & $1.81^{\mathrm{bc}}$ & $14.07^{\mathrm{ab}}$ \\
Selection 14 & $38.13^{\mathrm{c}}$ & 0.95 & $1.83^{\mathrm{bc}}$ & $18.16^{\mathrm{a}}$ \\
Merlot & $57.80^{\mathrm{abc}}$ & 0.84 & $1.76^{\mathrm{bc}}$ & $8.64^{\mathrm{d}}$ \\
Sauvignon Blanc & $72.07^{\mathrm{ab}}$ & 0.86 & $1.14^{\mathrm{cd}}$ & $11.60^{\mathrm{bcd}}$ \\
Chardonnay & $68.21^{\mathrm{ab}}$ & 0.82 & $0.64^{\mathrm{d}}$ & $9.51^{\mathrm{cd}}$ \\
Cabernet Sauvignon & $55.36^{\mathrm{abc}}$ & 0.79 & $0.74^{\mathrm{d}}$ & $13.20^{\mathrm{bc}}$ \\
Malbec & $52.30^{\mathrm{bc}}$ & 0.91 & $0.99^{\mathrm{cd}}$ & $9.98^{\mathrm{bcd}}$ \\
Petit Verdot & $54.78^{\mathrm{bc}}$ & 0.85 & $0.73^{\mathrm{d}}$ & $10.51^{\mathrm{bcd}}$ \\
Selection 47 & $51.31^{\mathrm{bc}}$ & 0.88 & $0.87^{\mathrm{bc}}$ & $11.08^{\mathrm{bcd}}$ \\
\hline Mean & 61.18 & 0.92 & 1.61 & 11.88 \\
CV $(\%)$ & 18.31 & 22.74 & 41.65 & 25.12 \\
\hline Means followed & & $0.05) ; \mathrm{ns}$. &
\end{tabular}

Means followed by the same letter in the column do not differ (Tukey's test, $p<0.05$ ); ns: not significant $(p<0.05)$.

$\mathrm{CV}$ : coefficient of variation, SP: mean sprouting, BF: bud fertility rate, PR: production, NC: number of clusters. 
The cultivars Grenache and Tempranillo for red wines and Chenin Blanc for white wines were the most productive, with significant differences compared to Sauvignon Blanc, Chardonnay, Cabernet Sauvignon, Malbec and Petit Verdot, whose productions were less than $1 \mathrm{~kg} / \mathrm{vine}$ (Table 1). These results allow estimating average yield around 10.4, 8.7 and 8.3 tons/ha/growing season, respectively, for Grenache, Chenin Blanc and Tempranillo (Fig. 1).

The production per vine and estimated yield observed in this study were less than those obtained for the same cultivars and the same region [8]. Higher yield, cluster and berry weight in cultivars Grenache and Tempranillo were also observed in previous study [8]. Cabernet Sauvignon, growing in Maringá, north region of Paraná state, Brazil, also showed higher yield than those observed in this work [9]. On the other hand, Merlot, growing in Bento Gonçalves, Rio Grande do Sul state, showed higher cluster and berry weight than those obtained in this study [10]. These differences among the same wine grape cultivars can be explained by variations among different clones, environmental conditions and vineyard management. However, it is possible that these cultivars have less adaptation and capacity in semiarid tropical conditions.

The ratio between fruit weight and pruned branch weight defined by the Ravaz index [11] differed significantly among cultivars and breeding selections. Grenache, Merlot and Tempranillo showed satisfactory balance between production and plant vigor and differed significantly from most other cultivars. In other cultivars and selections, the values were below the minimum limits [11], indicating an imbalance, consequence of low production and intense vegetative development.

Selection 14 and Syrah showed the highest number of bunches per vine (Table 1). However, the bunches had lower mean weight, which did not contribute to the increase in production in these cultivars. Bunches with higher mean weight were found in the cultivar Grenache (Table 2), differing from all other cultivars and selections. Moreover, longer and wider bunches were obtained in the cultivar Tempranillo and selections 14,47 and 46 . The lower compactness of bunches in breeding selections could contribute to reducing the incidence of common pests and diseases

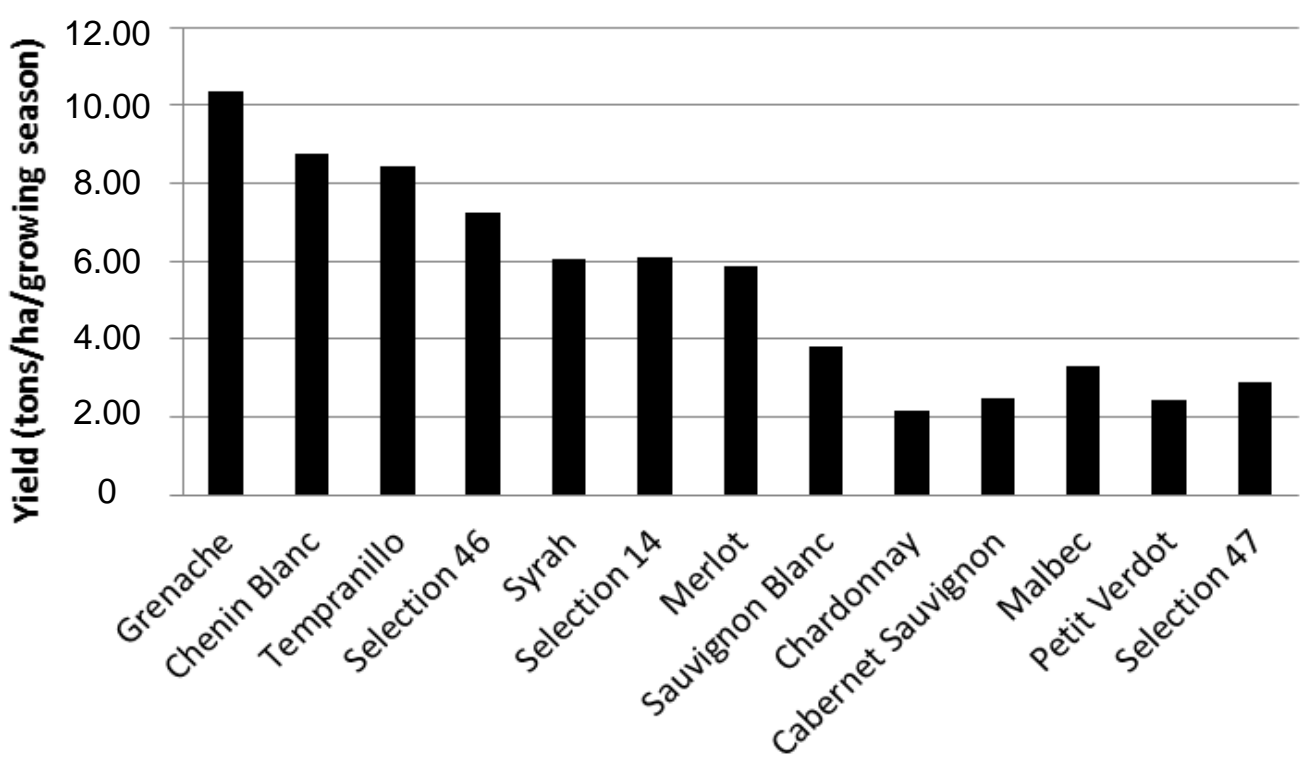

Fig. 1 Mean yield of wine grape cultivars and breeding selections in four consecutive growing seasons, Petrolina, Pernambuco state, 2014-2015. 
problems in wine grapes, such as honeydew moth, Cryptoblabes gnidiella (Lepidoptera: Pyralidae) and bunch rots of ripening grapes.

Cabernet Sauvignon, Sauvignon Blanc, Chardonnay and Petit Verdot had small bunches and low mean weight, less than $110 \mathrm{~g}$ (Table 2). Then, those cultivars have showed less adaption to the tropical semiarid conditions, being important to select and evaluate other clones in this region.

The greatest weight and volume of berries were observed in selection 46, Chenin Blanc and Grenache (Table 3), which could explain the higher average weight of bunches and production presented in the last two cultivars.

Table 2 Mean Ravaz index (kg of grapes/kg of branches), bunch weight (g), bunch length (cm) and bunch width (cm) of wine grape cultivars and breeding selections, Petrolina, Pernambuco state, 2014-2015.

\begin{tabular}{|c|c|c|c|c|}
\hline Cultivars/selections & $\mathrm{RI}$ & $\mathrm{BW}$ & $\mathrm{BL}$ & BWi \\
\hline Grenache & $7.56^{\mathrm{a}}$ & $306.89^{\mathrm{a}}$ & $13.62^{\mathrm{bc}}$ & $9.37^{\mathrm{bc}}$ \\
\hline Chenin Blanc & $4.60^{\mathrm{bcd}}$ & $223.12^{\mathrm{b}}$ & $12.70^{\mathrm{cd}}$ & $8.25^{\mathrm{cd}}$ \\
\hline Tempranillo & $5.93^{\mathrm{ab}}$ & $242.60^{\mathrm{b}}$ & $15.52^{\mathrm{a}}$ & $10.71^{\mathrm{a}}$ \\
\hline Selection 46 & $4.53^{b c d}$ & $161.87^{\mathrm{c}}$ & $14.04^{\mathrm{abc}}$ & $10.60^{\mathrm{ab}}$ \\
\hline Syrah & $4.29^{\text {cde }}$ & $141.90^{\mathrm{cd}}$ & $11.88^{\mathrm{d}}$ & $7.12^{\mathrm{def}}$ \\
\hline Selection 14 & $3.44^{\mathrm{def}}$ & $118.02^{\text {cde }}$ & $15.61^{\mathrm{a}}$ & $11.54^{\mathrm{a}}$ \\
\hline Merlot & $6.50^{\mathrm{ab}}$ & $110.45^{\mathrm{def}}$ & $11.53^{\mathrm{de}}$ & $7.10^{\mathrm{def}}$ \\
\hline Sauvignon Blanc & $2.57^{\mathrm{defg}}$ & $106.65^{\mathrm{def}}$ & $9.68^{\mathrm{fg}}$ & $6.59^{\mathrm{efg}}$ \\
\hline Chardonnay & $2.78^{\mathrm{defg}}$ & $94.87^{\mathrm{fg}}$ & $8.87^{\mathrm{fg}}$ & $6.00^{\mathrm{fg}}$ \\
\hline Cabernet Sauvignon & $1.07^{\mathrm{g}}$ & $68.63^{\mathrm{g}}$ & $8.36^{\mathrm{g}}$ & $5.47^{\mathrm{g}}$ \\
\hline Malbec & $2.37^{\mathrm{efg}}$ & $133.05^{\text {cde }}$ & $11.60^{\mathrm{de}}$ & $7.95^{\mathrm{d}}$ \\
\hline Petit Verdot & $2.75^{\mathrm{defg}}$ & $101.34^{\mathrm{efg}}$ & $10.16^{\mathrm{ef}}$ & $7.49^{\mathrm{de}}$ \\
\hline Selection 47 & $2.05^{\mathrm{fg}}$ & $89.93^{\mathrm{fg}}$ & $14.59^{\mathrm{ab}}$ & $11.27^{\mathrm{a}}$ \\
\hline Mean & 3.88 & 146.10 & 12.17 & 8.42 \\
\hline CV (\%) & 42.88 & 14.91 & 8.51 & 13.94 \\
\hline
\end{tabular}

Means followed by the same letter in the column do not differ (Tukey's test, $p<0.05$ ).

RI: mean Ravaz index, BW: bunch weight, BL: bunch length, BWi: bunch width, CV: coefficient of variation.

Table 3 Mean berry weight $(\mathrm{g})$, volume of 100 berries $(\mathrm{mL})$, soluble solids content $\left({ }^{\circ}\right.$ Brix) and titratable acidity (\% of tartaric acid) of wine grape cultivars and breeding selections, Petrolina, PE, 2014-2015.

\begin{tabular}{lllll}
\hline Cultivars/selections & BeW & BeV & SS & TA \\
\hline Grenache & $1.75^{\mathrm{b}}$ & $154.38^{\mathrm{bc}}$ & $19.1^{\mathrm{g}}$ & $0.82^{\mathrm{abc}}$ \\
Chenin Blanc & $1.74^{\mathrm{ab}}$ & $160.21^{\mathrm{b}}$ & $20.9^{\mathrm{cd}}$ & $0.86^{\mathrm{ab}}$ \\
Tempranillo & $1.59^{\mathrm{cd}}$ & $146.39^{\mathrm{cd}}$ & $22.3^{\mathrm{def}}$ & $0.72^{\mathrm{cd}}$ \\
Selection 46 & $1.99^{\mathrm{a}}$ & $177.50^{\mathrm{a}}$ & $23.3^{\mathrm{c}}$ & $0.81^{\mathrm{abc}}$ \\
Syrah & $1.52^{\mathrm{cde}}$ & $135.42^{\mathrm{de}}$ & $21.0^{\mathrm{def}}$ & $0.76^{\mathrm{bc}}$ \\
Selection 14 & $1.47^{\mathrm{de}}$ & $125.42^{\mathrm{e}}$ & $25.6^{\mathrm{b}}$ & $0.76^{\mathrm{bc}}$ \\
Merlot & $1.16^{\mathrm{f}}$ & $99.44^{\mathrm{fg}}$ & $19.8^{\mathrm{efg}}$ & $0.63^{\mathrm{d}}$ \\
Sauvignon Blanc & $1.53^{\mathrm{cd}}$ & $110.21^{\mathrm{f}}$ & $21.2^{\mathrm{de}}$ & $0.79^{\mathrm{abc}}$ \\
Chardonnay & $1.40^{\mathrm{e}}$ & $110.63^{\mathrm{f}}$ & $19.7^{\mathrm{fg}}$ & $0.82^{\mathrm{abc}}$ \\
Cabernet Sauvignon & $1.07^{\mathrm{fg}}$ & $93.54^{\mathrm{g}}$ & $18.8^{\mathrm{g}}$ & $0.78^{\mathrm{abc}}$ \\
Malbec & $1.60^{\mathrm{c}}$ & $135.28^{\mathrm{de}}$ & $19.8^{\mathrm{efg}}$ & $0.76^{\mathrm{bc}}$ \\
Petit Verdot & $0.97^{\mathrm{g}}$ & $89.58^{\mathrm{g}}$ & $23.1^{\mathrm{c}}$ & $0.88^{\mathrm{a}}$ \\
Selection 47 & $1.12^{\mathrm{f}}$ & $98.89^{\mathrm{fg}}$ & $27.2^{\mathrm{a}}$ & $0.89^{\mathrm{a}}$ \\
\hline Mean & 1.49 & 125.91 & 21.7 & 0.79 \\
CV $(\%)$ & 7.11 & 7.83 & 4.35 & 8.84 \\
\hline Means & & 1.83 &
\end{tabular}

Means followed by the same small letter in the column do not differ (Tukey's test, $p<0.05$ ).

$\mathrm{BeW}$ : mean berry weight, BeV: volume of 100 berries, SS: soluble solids content, TA: titratable acidity, CV: coefficient of variation. 
Considering the soluble solids, three groups of cultivars with higher, intermediate and low contents can be distinguished, characterizing grapes with different enological potential. The Embrapa breeding selections and cultivar Petit Verdot presented soluble solids contents above $23{ }^{\circ}$ Brix, showing high capacity to accumulate sugars (Table 3). Four cultivars showed intermediate contents, ranging from $20.9{ }^{\circ}$ Brix (Chenin Blanc) to $22.3{ }^{\circ}$ Brix (Tempranillo). Lower soluble solids contents were found in cultivars Malbec, Merlot, Chardonnay, Grenache and Cabernet Sauvignon.

There were also significant differences among cultivars regarding the titratable acidity (Table 3). However, most of them showed values above $0.75 \%$ tartaric acid. Merlot and Tempranillo had the lowest values, and was the first one differed significantly from others cultivars and selections.

\section{Conclusions}

Cultivars Grenache and Tempranillo showed better agronomic performance, being good new options for red wines.

Traditional cultivars, such as Sauvignon Blanc, Chardonnay, Cabernet Sauvignon, Malbec and Petit Verdot presented low yield and unbalanced vines, being necessary to select better clones.

Petit Verdot, despite its low yield, was highlighted by the high content of sugars and acidity of their grapes, which can be interesting for high quality wines.

Further studies on physical-chemical and sensory characteristics of the wines are necessary to enable the indication of wine grape cultivars with potential for the São Francisco Valley.

\section{References}

[1] Agrianual. 2016. Yearbook of Brazilian Agriculture. São Paulo: FNP Consulting, 448-56.

[2] SEBRAE. 2007. Brazilian Wines: The World Tastes Brazil. Porto Alegre: SEBRAE, 45.

[3] Embrapa Semiarid. 2015. "Annual Averages of the Bebedouro Agrometeorological Station." Accessed March 16, 2015. http://www.cpatsa.embrapa.br: 8080/servicos/dadosmet/ceb-anual.html.

[4] De Souza Leão, P. C., and Rodrigues, B. L. 2009. "Canopy Management." In The Vitiviniculture in the Brazilian Semi-Arid, edited by Soares, J. M., and Leão, P. C. Brasilia, DF: Embrapa Technological Information and Petrolina, PE: Embrapa Semi-Arid, 295-347.

[5] Pereira, G. E. 2013. "The Tropical Wines in Development in Northeast Brazil." Com Ciência, Campinas (149): 1-3.

[6] Lima, M. A. C. 2013. Arrangement of Projects: Innovations and Competitiveness of Winemaking in the Semi-Arid. Petrolina: Embrapa Semi-Arid, 21.

[7] Association of Official Agricultural Chemists (AOAC). 1992. Official Methods of Analysis of the Association of the Agricultural Chemistry. 11th ed.. Washington: AOAC, 1115.

[8] Camargo, U. A., De Amorim, F. M., Guerra, C. C., and Lima, M. V. D. O. 2004. "Introduction and Evaluation of New Cultivars for Wine in the São Francisco Valley." Presented at the 1st International Research Workshop: The Production of Wines in Tropical Regions, 103-9.

[9] Sato, A. J., Da Silva Jubileu, B., De Assis, A. M., and Roberto, S. R. 2011. "Phenology, Production and Must Compounds of 'Cabernet Sauvignon' and 'Tannat' Grapevines in Subtropical Climate.” Brazilian Journal of Fruit Growing 33 (2): 491-9.

[10] Rizzon, L. A., and Miele, A. 2003. "Evaluation of CV. Merlot for Elaboration of Red Wine." Food Science and Technology (Campinas) 23: 156-61.

[11] Smart, R., and Robinson, M. 1991. Sunlight into the Wine: A Handbook for Winegrape Canopy Management. Adelaide, Austrália: Winetitles. 